\title{
DAKWAH DALAM PENDEKATAN NILAI-NILAI KEARIFAN LOKAL (Tinjauan Dalam Perspektif Internalisasi Islam dan Budaya)
}

\author{
Oleh: \\ Dr. H. Abdul Wahid, M.A \\ **Dosen STIE Tri Dharma Nusantara Makassar** \\ Email:wahidnasywa@gmail.com
}

\begin{abstract}
ABSTRAK
Tulisan ini memuat tentang pendekatan nilai-nilai kearifan lokal dalam kegiatan dakwah. Sebagaimana kita maklum bahwa dakwah bukanlah tujuan tapi alat untuk mencapai tujuan tersebut. Secara umum tujuan dakwah adalah untuk mengarahkan dan mendorong umat manusia agar masuk Islam. Karena itu, pada prinsipnya Islam dan budaya tidak bertentangan, sebab keduanya sama-sama mengajarkan nilai-nilai kebaikan yang tujuannya membuat keteraturan bagi sekelompok manusia. Karena itu, dalam konteks dakwah maka yang terpenting adalah bagaimana seorang da'i harus mampu memahami nilai-nilai historis dan filosofis dari budaya yang berkembang di masyarakat, kemudian diinternalisasi dengan nilai-nilai keislaman. Walhasil lahirlah model budaya baru yang bisa disebut "budaya Islami". Agama Islam mengajarkan kepada manusia nilai-nilai normatif untuk menerapkan keadilan, kejujuran, persamaan, kebebasan, persaudaraan, kebebasan dan musyawarah, yang kesemuanya itu dalam rangka mewujudkan suatu tata kehidupan masyarakat dan negara yang sebaik-baiknya untuk kemaslahatan hidup yang berkesinambungan, baik kehidupan individual maupun kehidupan sosial. Dan bahwa "pada dasarnya universalisme ajaran (agama) Islam telah memuat prinsip-prinsip dasar mengenai hubungan-hubungan individu dan hubunganhubungan sosial yang kemudian pengejawantahan nilai-nilai kemanusiaan tersebut secara subtansial.
\end{abstract}

Kata Kunci: Dakwah dan Kearifan Lokal: Dakwah dan Budaya.

\section{ABSTRACT}

This paper contains about the approach of local wisdom values in da'wah activities. As we know that dakwah is not a goal but a tool to achieve that goal. In general the purpose of da'wah is to direct and encourage mankind to convert to Islam. Therefore, in principle Islam and culture are not contradictory, because they both teach the values of goodness whose purpose is to make order for a group of people. Therefore, in the context of da'wah then the most important is how a da'i should be able to understand the historical and philosophical values of the culture that developed in society, then internalized with Islamic values. As a result a new cultural model that can be called "Islamic culture" is born. Islam teaches humanity normative values to apply justice, honesty, equality, freedom, brotherhood, freedom and 
deliberation, all of which are in order to realize a good life of society and state for the sake of life that is sustainable, both individual life and social life. And that "basically the universalism of Islamic (religious) teachings has contained the basic principles of individual relations and social relations which subsequently manifested human values substantially.

Keywords: Da'wah and Local Wisdom: Da'wa and Culture.

\section{PENDAHULUAN}

Kehadiran dan keberadaan Islam di tengah kehidupan manusia tidak untuk menjadi tandingan dari budaya yang telah berkembang di masyarakat, justru ingin menjadikan nilai-nilai budaya yang merupakan kearifan lokal tersebut sebagai salah satu instrumen dakwah.

Hanya saja, harus diakui bahwa masih ada sebagian para da'i yang salah memposisikan keberadaan budaya itu sendiri. Misalnya saja ada diantara para da'i yang beranggapan bahwa budaya tidak perlu dipertahankan karena tidak berasal dari al-Qur'an dan hadits. Padahal untuk menjawab anggapan ini dapat dikemukakan bahwa tidak selamanya sesuatu yang tidak berdasar secara eksplisit dalam al-Qur'an dan hadits sudah otomatis salah sehingga harus ditinggalkan. Rasulullah saw. pernah mengingatkan "Kamu lebih mengetahui urusan duniamu." (HR. Muslim, no. 2363).

Islam hadir di ke bumi bukan dalam posisi untuk menghapus budaya yang telah ada di tengah masyarakat, akan tetapi kehadiran Islam adalah sebagai upaya internalisasi ajaran Islam ke dalam budaya. Sebagaimana telah diketahui bahwa tidak ada satu pun manusia, yang luput dari pengaruh budaya, sebab budaya lahir seiring dengan lahirnya manusia di muka bumi ini.

Manusia adalah mahluk berbudaya. Manusia secara organis hampir tak memiliki perbedaan yang mencolok antar satu dengan lainnya, apalagi pada manusia yang terlahir pada masa sekarang. Perbedaan manusia paling krusial dan justeru karena perbedaan watak kepribadian dan sangat berpengaruh terhadap pola kebudayaannya. ${ }^{1}$

\footnotetext{
${ }^{1}$ Acep Aripudin, Sosiologi Dakwah, (Bandung: Rosda Karya, 2013), h. 56.
} 
Dalam memposisikan manusia sebagai mahluk yang berbudaya dengan seluruh dinamikanya, maka dakwah harus mampu diperankan dengan adaptif terhadap eksistensi budaya itu sendiri, agar tidak terjadi jurang pemisah antara ajaran wahyu dan dinamika sosial-budaya dalam masyarakat.

Karena itu dalam tulisan ini, maka ada beberapa hal yang akan diungkap diantaranya; (1) bagaimana model dakwah kultural, (2) bagaimana cara menerapkan dakwah al-Hikmah dalam perspektif Kerifan Lokal dan (3) bagaimana peran dakwah Kultural dalam mendorong terwujudnya perubahan sosial.

\section{BAHASAN}

\section{A. Reeinterpretasi Model Dakwah Kultural}

Dakwah kultural terdiri dari dua kata yakni dakwah dan kultural. Akan tetapi dalam tulisan ini akan khusus dijelaskan dengan singkat makna kultural yang diartikan ke dalam bahasa Indonesia dengan budaya (kebudayaan).

Merujuk pada Kamus Umum Bahasa Indonesia, kebudayaan diartikan sebagai hasil kegiatan dan penciptaan batin (akal budi) manusia seperti kepercayaan, kesenian, adat istiadat; dan berarti pula kegiatan (usaha) batin, akalbudi dan sebagainya untuk menciptakan sesuatu yang termasuk hasil kebudayaan. $^{2}$

Sementara dalam pandangan Sutan Tadir Alisjahbana disebutkan, kebudayaan adalah keseluruhan yang kompleks yang terjadi dari unsur-unsur yang berbeda seperti pengetahuan, kepercayaan, seni, hukum, moral, adat istiadat, dan segala kecakapan lain yang diperoleh manusia sebagai anggota masyarakat. ${ }^{3}$

Dengan demikian kebudayaan adalah hasil daya cipta manusia menggunakan dan mengarahkan segenap potensi yang dimiliki. Kebudayan ini terwujud melalui pikiran, adat istiadat, kesenian dan sebagainya.

2 W.J.S. Poerwadarminta, Kamus Umum Bahasa Indonesia, (Jakarta: Balai Pustaka, 1991), h. 156.

${ }^{3}$ Sutan Takdir Alisyahbana, Antropologi Baru, (Jakarta: Dian Rakyat, 1986), h. 207. 
Budaya adalah gaya hidup yang unik suatu kelompok manusia tertentu. Budaya bukanlah sesuatu yang dimiliki sebagian orang dan tidak dimiliki sebagian yang lainnya. Budaya dimiliki oleh seluruh manusia dan demikian sebagai suatu faktor pemersatu. Budaya merupakan pengetahuan yang dapat dikomunikasikan sifat-sifat, perilaku dan dipelajari yang juga ada pada anggotaanggota suatu kelompok sosial lainnya. Karena itu E.B. Taylor bapak antropologi budaya memberi definisi, budaya sebagai keseluruhan kompleks yang meliputi pengetahuan, kepercayaan, seni, moral, hukum, adat istiadat, dan kemampuankemampuan atau kebiasaan-kebiasaan lain yang diperoleh anggota suatu masyarakat. $^{4}$

Karena itu, kebudayaan selanjutnya dapat digunakan untuk memahami agama secara empiris atau agama yang tampil dalam bentuk formal yang menggejala di masyarakat. Pengamalan agama yang terdapat di masyarakat tersebut diproses oleh penganutnya dari sumber agama yaitu wahyu dari penalaran. Kita misalnya membuka kitab fiqh, yang merupakan pelaksanaan dar nash al-Qur'an maupun hadis Nabi Saw.agama menjadi membudaya atau membumi di tengah masyarakat. Agama yang tampil dalam bentuknya yang demikian itu berkaitan dengan kebudayaan yang berkembang di suatu masyarakat tempat agama itu berkembang. Sekali lagi dengan melalui pemahaman terhadap kebudayaan tersebut seseorang akan dapat membantu mengamalkan ajaran agamanya. ${ }^{5}$

Sebagaimana kita maklum bersama bahwa Islam hadir ke tengah-tengah bangsa Arab Mekah-Madinah pada masa silam tidak terlepas dari adanya interaksi antara nilai-nilai budaya lokal dan ajaran wahyu yang dibawa oleh Rasulullah saw. Sebut saja misalnya bagaimana Islam secara bertahap melarang minumminuman keras. Pentahapan ini harus dipahami sebagai salah satu strategi dakwah

${ }^{4}$ E.B. Taylor dalam, Deddy Mulyana dan Jalaluddin Rakhmat (ed.), Komunikasi Antar Budaya: Panduan Berkomunikasi Dengan Orang-Orang Berbeda Budaya, (Cet. XII., Bandung: Rosda Karya, 2010), h. 56.

${ }^{5}$ Abuddin Nata, Metodologi Studi Islam, (Cet. XIX; Jakarta: Raja Grafindo Persada, 2012), h. 49-50. 
yang diterapkan oleh Rasulullah saw. saat itu kepada masyarakat Arab Jahiliyah.

Berikut tahapan pelarangan khamr yang disebutkan dalam al-Qur'an yakni:

Pertama, tahap awal. Disebutkan dalam al-Qur'an.

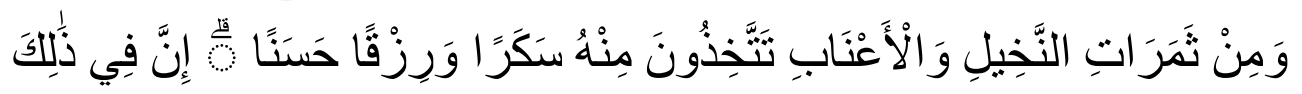

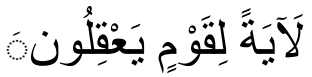

"Dan dari buah korma dan anggur, kamu buat minuman yang memabukkan dan rezki yang baik. Sesunggguhnya yang demikian itu benar-benar terdapat tanda kebesaran Allah bagi orang yang memikirkan. (QS. an Nahl: 67).

Pada ayat di atas Allah sama sekali tidak menyinggung tentang dosa dan juga keharaman bagi peminum khamr. Dengan kata lain pada saat awal Islam yang di bawa oleh Nabi Muhammad saw. datang khamr bukanlah minuman yang haram untuk dikonsumsi.

Kedua, tahap kedua. Turunlah ayat berikut:

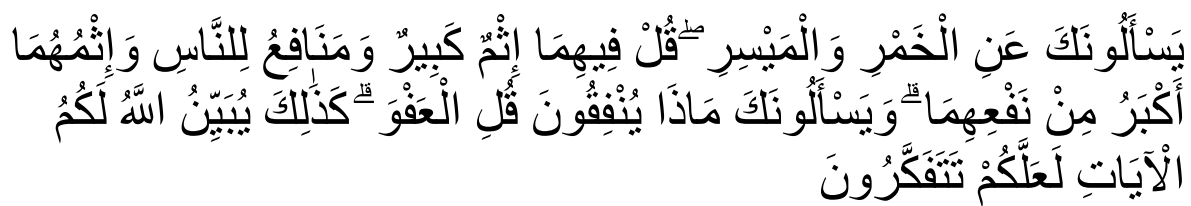

"Mereka bertanya kepadamu tentang khamar dan judi. Katakanlah: "Pada keduanya terdapat dosa yang besar dan beberapa manfaat bagi manusia, tetapi dosa keduanya lebih besar dari manfaatnya". (QS. al-Baqarah [2]: 219).

Mudjab Mahalli menyebutkan bahwa ayat tersebut adalah ayat pertama yang menyinggung tentang khamar. ${ }^{6}$ Ayat itu turun ketika Nabi saw. pertama kali memasuki kota Madinah. Pada saat itu Beliau mendapati penduduk Madinah gemar meminum arak (minuman yang memabukkan) dan makan dari hasil perjudian.

Kemudian mereka menanyakan tentang kebiasaan tersebut. Sehubungan dengan hal itu Allah menurunkan ayat di atas untuk menjawab pertanyaan tersebut. Setelah mendapat jawaban mereka berkata "Tidak diharamkan kita meminum khamar, hanya saja berdosa besar". Oleh sebab itu mereka meneruskan

6 A. Mudjab Mahalli, Asbabun Nuzul (studi Pendalaman Alquran), Jakarta: PT Raja GrafindoPersada, 2002, h. 94. 
kebiasaan tersebut. ${ }^{7}$

Ketiga, Tahap ketiga, turunlah ayat berikut:

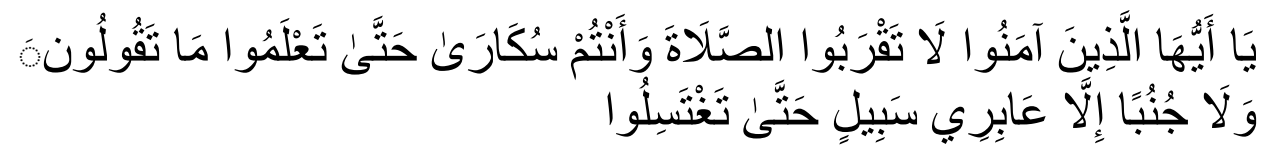

"Hai orang-orang yang beriman, janganlah kamu shalat, sedang kamu dalam Keadaan mabuk, sehingga kamu mengerti apa yang kamu ucapkan". (QS. an Nisa [4]: 43).

Ayat di atas merupakan tahapan selanjutnya sebelum pemberian label haram pada khamar. Imam Alqurtubhi dalam tafsirnya menyebutkan bahwa ayat tersebut turun dilatar belakangi suatu kejadian dimana ada seorang laki-laki yang meminum khamar kemudian maju untuk mengimami shalat. Karena khamar yang diminum menyebabkan ia mabuk, bacaan yang dibacanya pun menjadi keliru. Ketika ayat di atas telah turun ternyata masyarakat muslim itu belumlah dapat meninggalkan kebiasaan mereka meminum minuman keras. Di samping itu memang belum ada larangan tegas tentang keharaman meminumnya.

Keempat, tahap keempat, sebagai kelanjutan dari ayat di atas, maka Allah swt. menurunkan ayat berikut:

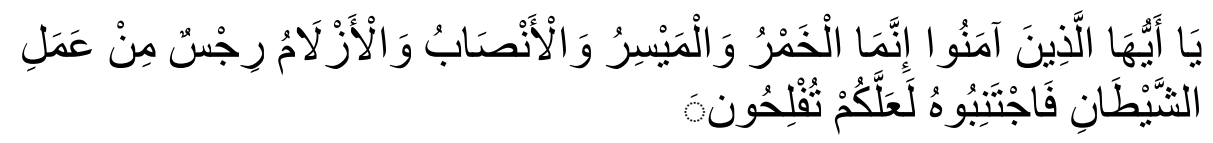

"Hai orang-orang yang beriman, sesungguhnya meminum khamar, berjudi, berkorban untuk berhala, mengundi nasib dengan panah, adalah termasuk perbuatan syaitan. Maka jauhilah perbuatan-perbuatan itu agar kamu mendapat keberuntungan". (QS. al-Maidah [5]: 90).

Ayat di atas merupakan akhir dari tahap pengharaman khamar. Setelah ayat tersebut turun maka khamar menjadi haram. Imam Al-Qurthubi menyebutkan bahwa sampai-sampai sebagaian umat Islam mengatakan bahwa Allah swt. tidak pernah mengharamkan sesuatu yang sangat dahsyat kecuali masalah khamar. ${ }^{8}$

Salah satu hikmah yang dapat kita ambil dari tahapan-tahapan

${ }^{7}$ Ibid., h. 343.

${ }^{8}$ Imam Al-Qurthubi, Tafsir Al-Qurthubi Juz 5, alih bahasa Ahmad Rijali Kadir, (Jakarta: Pustaka Azzam, 2008), h. 683. 
pengharaman khamar ialah hal ini membuktikan bahwa Islam bukanlah agama yang memberatkan umatnya. Islam mengajarkan bahwa untuk mencapai suatu tujuan yang besar diperlukan tahapan yang tidak sebentar. Dalam konteks dakwah, maka dapat dipahami bahwa seorang da'i dalam mentransformasikan ajaran Islam harus memahami kondisi ril masyarakat, sehingga mulai dari materi, metode dan lainnya dapat direlevansikan di lapangan agar tujuan dakwah dapat tercapai maksimal.

\section{B. Penerapan Dakwah al-Hikmah Dalam Perspektif Kerifan Lokal}

Salah satu identitas suatu masyarakat dengan lainnya adalah dimana disetiap masyarakat memiliki kerifan lokal yang lahir dari nilai-nilai ketulusan dan kearifan di tengah masyarakat tersebut. Karena itu, banyak nilai-nilai kearifan lokal yang relevan dengan ajaran agama misalnya nilai "penghormatan kepada orang lain", nilai kejujuran dan keadilan. Semua ini sesungguhnya adalah bagian dari nilai-nilai Islam yang berasal dari wahyu.

Karena itu, disinilah perlunya pemahaman yang utuh dari seorang da'i dalam mengemban misi dakwah di tengah umat. Dari sini pula kemudian dikenal istilah "dakwah kultural".

Dakwah kultural memiliki hubungan yang dekat dengan Islam kultural, karena dakwah kultural menekankan pendekatan Islam kultural. Kata kultural sendiri yang berada di belakang kata Islam berasal dari bahasa Inggris, culture yang berarti kesopanan, kebudayaan, dan pemeliharaan. Teori lain mengatakan bahwa culture berasal dari bahasa latin cultura yang artinya memelihara, mengerjakan, dan mengolah. Sementara itu Koentjaraningrat membagi kebudayaan dalam tiga wujud, (1) wujud ideal, yaitu wujud kebudayaan sebagai suatu kompleks ide-ide, gagasan, nilai-nilai, norma-norma, peraturan dan sebagainya, (2) wujud kelakuan, yaitu wujud kebudayaan sebagai suatu kompleks aktifitas kelakuan berpola dari manusia dalam masyarakat, dan (3) wujud benda, yaitu wujud kebudayaan sebagai benda-benda hasil karya. ${ }^{9}$

\footnotetext{
${ }^{9}$ Sutan Takdir Alisyahbana, Op.cit., h. 205.
} 
Dengan demikian, yang dimaksud dengan Islam kultural adalah Islam yang dipahami dengan pendekatan kebudayaan atau Islam yang dipengaruhi oleh paham atau konsep kebudayaan sangat dimungkinkan. Munculnya Islam kultural agak mudah dimengerti apabila kita memperhatikan ruang lingkup ajaran Islam, yang tidak hanya mencakup masalah keagamaan, seperti teologi, ibadah, dan akhlak, melainkan juga mencakup masalah keduniaan, seperti masalah ekonomi, pertahanan keamanan, ilmu pengetahuan, tehnologi, politik, keluarga. Jika masalah agama peran Allah dan Rasul-Nya demikian dominan, maka pada aspek keduniaan peran manusialah yang paling dominan. Pada aspek keduniaan ini, Allah dan Rasul-Nya hanya menetapkan prinsip-prinsip etikanya saja, sedang tata cara dan ekspresinya terserah manusia. Dalam situasi yang demikian inilah kebudayaan memiliki peran dan memberi pengaruh yang besar terhadap agama. Islam kultural adalah Islam yang lebih dapat beradaptasi dengan lingkungan sosialnya, dimana Islam tersebut dipraktekkan. ${ }^{10}$

Dakwah kultural pada awalnya merupakan gagasan alternatif bagi solusi konflik pada diri manusia, antar individu maupun antar kelompok. ${ }^{11}$ Lebih jauh Aripudin menyebutkan bahwa wujud produk dakwah antarbudaya ketika terjadi proses interaksi antara nilai-nilai Islam dengan budaya-budaya lokal, akan menghasilkan wujud budaya Islami yang bertentangan masing-masing nilai (resistensi), terjadi pembauran (akulturasi), penerimaan salah satunya (receipt), sehingga menimbulkan hegemoni nilai budaya atau terjadi perpaduan yang saling mengisi (komplementer). ${ }^{12}$ Sistem nilai Islam yang menjadi komoditi dakwah, sebagaimana wataknya, memang sangat lentur dan fleksibel. Persentuhan budaya Islam ketika mengakomodasi produk budaya manusia sejak dahulu hingga sekarang telah melahirkan budaya-budaya baru yang terus berkembang secara dinamis, dialektikanya akomodatif. Dinamika ini sekaligus menjadi taruhan yang tak terbantahkan bahwa Islam akan selalu hidup sesuai zaman dan perkembangan

\footnotetext{
${ }^{10}$ Abuddin Nata, Peta Keragaman Pemikiran Islam Di Indonesia, (Jakarta: Raja Grafindo Persada, 2001), h.175-177.

${ }^{11}$ Acep Aripudin, Op.cit., h. 57.

${ }^{12}$ Ibid.
} 
budaya manusia. $^{13}$

Mengacu dari asumsi di atas, maka dapat dipahami bahwa dakwah kultural adalah sebuah upaya untuk mentranspormasikan pesan-pesan Islam kepada masyarakat tertentu dengan tetap memperhatikan realitas sosial yang ada, dengan prinsip bahwa bagaimana caranya agar Islam "tidak bertentangan” dengan kebiasaan masyarakat yang telah diyakini secara turun temurun, sebagaimana disinyalir oleh Allah pada ayat berikut:

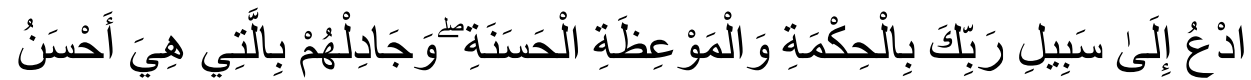

"Serulah manusia kepada jalan Tuhanmu dengan hikmah dan pelajaran yang baik dan bantahlah mereka dengan cara yang baik... (QS. an Nahl [16]: 125).

Memahami ayat ini dengan mulai dari kata al-Hikmah dapat dijabarkan dengan dakwah yang diperankan dengan cara-cara yang santun, relevan dengan kebutuhan dan kondisi umat atau dengan kata lain dakwah yang selalu menjadikan nilai-nilai lokal yang ada dalam masyarakat sebagai salah satu instrumen dakwah.

Pemahaman yang hampir sama disebutkan oleh Didin Hafidhuddin memahami istilah bi al-Hikmah pada ayat terbut dengan makna bahwa dakwah harus dilakukan dengan secara efesien, efektif, dan sesuai dengan kebutuhan, karena itu sudah saatnya dibuat dan disusun stratifikasi sasaran dakwah secara objektif. Selanjutnya menurutnya dakwah dalam pengertian yang integralistik merupakan suatu proses yang berkesinambungan, yang ditangani oleh para da'i untuk mengubah umat agar bersedia masuk ke jalan Allah Swt. secara bertahap menuju prikehidupan yang Islami. ${ }^{14}$

Di Indonesia juga kita pernah mendengar istilah "Demokrasi Berbasis Kultural" yang dipahami bahwa demokrasi bukanlah suatu tujuan melainkan sarana menuju suatu tujuan yang lebih hakiki dan luhur, yakni suatu proses demokrasi yang senantiasa memperhatikan kondisi dan budaya masyarakat dalam berbagai segmentasinya. ${ }^{15}$

\footnotetext{
${ }^{13}$ Ibid., h. 57-58.

${ }^{14}$ Didin Hafidhuddin, Dakwah Aktual, (Jakarta: Gema Insani, 1998), h. 79.

${ }^{15}$ Ahmad Suaedy, Perspektif Pesantren; Islam Indonesia Gerakan Sosial Baru Demokratisasi, (Cet. I; Jakarta: The Wahid Institut, 2009), h. 118.
} 
Doktrin agama memiliki horizon yang amat luas, doktrin itu menjadi sumber nilai bagi pembentukan kepribadian. Doktrin agama manapun yang dianut oleh komunitas manapun dibelahan dunia ini mengajarkan kepada pemeluknya untuk menjadi manusia yang baik,jujur, kasih sayang dan seterunsnya. Dengan demikian secara subtansi ajaran agama memberikan kerangka norma yang tegas bagi tingkah laku umatnya. ${ }^{16}$ Kendati demikian sering terjadi miskomunikasi antara nilai subtansi agama dengan pengaplikasian umatnya dilapangan yang dengan sendirinya ajaran agama tersebut "ternoda".

Islam sebagai agama wahyu yang mengajarkan kepada penganutnya untuk menyebarkan agama dengan cara hikmah dan bijaksana, agar dengan cara tersebut orang bisa menerima nilai-nilai humanis Islam, dan nilai-nilai bagi kemaslahatan bagi manusia dan alam. ${ }^{17}$

Dari sinilah kemudian dipahami bahwa Islam dalam konteks bahasa dakwah tidak mengenal dan mengajarkan kekerasan kepada penganutnya, karena dakwah adalah upaya luhur yang direfleksikan dengan berbagai tindakan nyata oleh para da'i dengan tujuan untuk memberikan arahan dan peringatan kepada realitas masyarakat sesuai dengan konteksnya.

\section{Dakwah Kultural dan Perubahan Sosial}

Dakwah Islam menghendaki perubahan masyarakat baik secara individu maupun secara kolektif, untuk mewujudkan perubahan tersebut dibutuhkan upaya yang sungguh-sungguh dan profesional oleh para aktivis dakwah.

Perubahan sosial adalah proses sosial yang dialami oleh anggota masyarakat serta semua unsur-unsur budaya dan sistem-sistem sosial, dimana semua tingkat kehidupan masyarakat secara sukarela atau dipengaruhi oleh unsurunsur eksternal meninggalkan pola-pola kehidupan, budaya dan sistem sosial

${ }^{16}$ Syarifuddin Jurdi, Sosiologi Islam dan Masyarakat Modern, (Yogyakarta: Kencana Prenada Media Group, 2010), h. 86.

${ }^{17}$ Ibid., h. 87. 
lainnya. ${ }^{18}$ Perubahan sosial terjadi ketika ada kesediaan anggota masyarakat untuk meninggalkan sistem sosial lama dan mulai memilih serta menggunakan pola dan sistem sosial yang baru. Perubahan sosial dipandang sebagai konsep yang mencakup seluruh kehidupan individu, kelompok, masyarakat, negara dan dunia yang mengalami perubahan. ${ }^{19}$

Berangkat dari pemahan di atas, maka menurut hemat penulis peran dakwah kultural setidaknya dapat diklasifikasi dengan tiga tahap yakni:

Pertama, Islam harus disebarkan kepada umat manusia dalam selalu berbasis bil-Hikmah. Artinya bahwa dakwah yang selalu berusaha memahami realitas umat secara totalitas, sehingga da'i ini akan berusaha menampilkan dakwah yang gemar merangkul bukan memukul, terutama yang terkait dengan nilai-nilai kearifan lokal. Walhasil dengan pendekatan al-Hikmah ini, kemudian seorang da'i akan mampu menyesuaikan strategi serta model dakwah yang akan dikembangkan kepada umat tersebut.

Hikmah dalam metode dakwah sebagaimana disebutkan oleh al-Qahthany tidak dibatasi hanya dengan dakwah melalui ucapan yang lembut, targhib (nasihat motivasi) seperti yang selama ini dipahami orang. Lebih dari itu hikmah berarti seluruh ta'lim dan tarbiyah, (nasihat yang baik) al-Mau'izah al-Hasanah, dialog yang baik pada tempatnya dan penentangnya. ${ }^{20}$

Dakwah yang hikmah dalam ranah dakwah kultural juga diartikan sebuah proses dakwah yang menegosiasikan antara ajaran Islam dengan budaya lokal, atau berdakwah dengan tetap menjunjung tinggi kearifan lokal dalam masyarakat. Wal hasil akan lahir sebuah parameter baru yakni mengislamisasi kebudayaan dalam masyarakat. Dakwah yang hikmah diartikan pula sebagai sebuah pergerakan dakwah yang diterapkan seorang da'i melalui “adaptasi” antara ajaran Islam yang berbasis kelangitan bisa dibumikan dalam kehidupan empiris. Hal ini relevan dalam satu ayat al-Qur'an sebagaimana disinyalir oleh Allah Swt. dalam

\footnotetext{
${ }^{18}$ Burhan Bungin, Sosiologi Komunikasi: Teori, Paradigma dan Diskursus Teknologi Komunikasi di Masyarakat, (Cet. IV; Jakarta:Kencana Prenada Group, 2009), h. 91.

${ }^{19}$ Ibid.

${ }^{20}$ Sa'id Bin 'Ali bin Wahif al-Qahtani, Al-Hikmah fi al-Da'wah ila Allah Ta'ala, terj. Mansyur Hakim, Dakwah Islam Dakwah Bijak, (Cet. I; Jakarta: Gema Insani Press, 1994), h. 23.
} 
al-Qur'an.

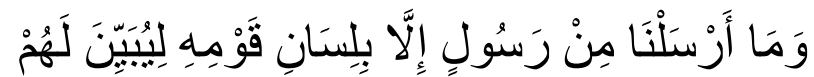

"Kami tidak mengutus seorang Rasulpun, melainkan dengan bahasa kaumnya... (QS. Ibrahim [14]: 4).

Menyimak ayat di atas dalam perspektif sosiologi maka dapat dipahami bahwa Nabi Muhammad saw. tidak berdakwah kepada orang Arab Jahiliyah kala itu, melainkan ia kemas dakwah tersebut berdasarkan kondisi sosial yang ada. Perintah menjauhi kemungkaran dalam bahasa dakwah menyangkut ajakan dan seruan pada nilai-nilai kebaikan dan kebenaran yang perinsipil, universal dan masih abstrak. ${ }^{21}$

Secara filosofis sepertinya akan sulit Islam itu diterima oleh masyarakat Arab Jahiliyah kala itu, jika bahasa serta ajaran Islam yang diperankan Nabi saw. tidak relevan dengan bahasa (kondisi) sosial-budaya saat itu. Sebab dakwah adalah ajakan yang tujuannya dapat tercapai hanya dengan persetujuan tanpa paksaan dari objek dakwah. Dakwah Islam merupakan ajakan untuk berpikir, berdebat dan berargumen, dan untuk menilai suatu kasus yang muncul. Dakwah Islam tidak dapat disikapi dengan keacuhan kecuali oleh orang bodoh atau berhati dengki. Hak berpikir merupakan sifat dan milik semua manusia.

Mentransfer nilai-nilai Islam ke orang lain, harus mampu dibahasakan sesuai dengan sosio-kultural masyarakat yang dihadapi. Agar dakwah dapat diperhitungkan sekaligus dirasakan peran dan fungsinya oleh umat. Membahasakan dakwah sesuai dengan basis kebutuhan yang prioritas dari mad'u adalah sebuah keniscayaan agar tidak terjadi jarak antara apa yang disampaikan oleh da'i dengan apa yang diterima dan pahami oleh mad'u.

Ke-rahmatan lil-'alamin ajaran Islam terletak pada subtansi ajarannya yang bersifat universal atau dengan bahasa Al-Qur'an Islam kaffah sebagaimana disebutkan dalam salah satu firman Allah swt.

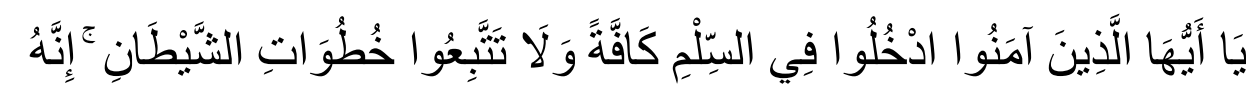

${ }^{21}$ Asep Muhiddin, Dakwah Dalam Perspektif Al-Qur'an, (Bandung: Pustaka Setia, 2002), h. 17. 


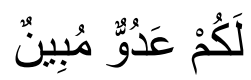

"Hai orang-orang yang beriman, masuklah kamu ke dalam Islam keseluruhan, dan janganlah kamu turut langkah-langkah syaitan. Sesungguhnya syaitan itu musuh yang nyata bagimu”. (QS. al-Baqarah [2]:208).

Ayat di atas jika dipahami dalam konteks dakwah kultural, maka pesanpesan Islam harus mampu diadaptasikan dengan budaya masyarakat, sepanjang budaya tersebut tidak bertentangan dengan nilai-nilai subtansi ajaran Islam itu sendiri. Karenanya, Islam yang kaffah (universal) adalah apabila dakwah mampu dihadirkan oleh para da'i dalam berbagai segmen budaya masyarakat, secara dinamis dan adaptif.

Memahami Islam dalam konteks ini maka Islam harus dijadikan sebagai way of life (panduan hidup) dengan demikian harus dikaitkan antara satu bagian dengan yang lainnya. Sebagai suatu tata nilai, Islam tidaklah sekedar baik sebagai landasan etis dan moral, tetapi ajarannya sangat bersifat operasional dan aplikatif dalam segala segi kehidupan manusia. ${ }^{22}$ Dengan demikian, sebagaimana yang telah dikemukakan di atas, bahwa hakikat dakwah menghendaki adanya perubahan sosial di tengah masyarakat, terkait dengan perubahan sosial tersebut oleh para ahli sosiologi memberikan klasifikasi perubahan yaitu:

a) Perubahan pola pikir (kognitif). Perubahan pola pikir masyarakat terhadap berbagai persoalan sosial dan budaya akan melahirkan pola pikir baru yang dianut oleh masyarakat di era modern.

b) Perubahan sikap (afektif). Perubahan sikap masyarakat menyangkut perubahan sistem-sistem sosial dimana masyarakat meninggalkan sistem yang lama dan beralih kepada sistem yang baru.

c) Perubahan perilaku (psikomotorik), perubahan ini terkait dengan kebiasaan atau budaya menyangkut perubahan artefak budaya yang digunakan oleh masyarakat seperti model pakaian, karya fotografi dan seterunsnya. ${ }^{23}$

Dalam pandangan Majdi Hilali dalam bukunya yang berjudul "Kaifa Nughayyir Ma bi Anfusina” (bagaimana kita mengubah perilaku diri), menurutnya

\footnotetext{
${ }^{22}$ Asep Muhiddin, Op.cit., h. 18.

${ }^{23}$ Burhan Bungin, Op.cit., h. 91-92.
} 
setiap perubahan masyarakat melalui tiga tahap yakni; akal, hati, dan hawa nafsu.perubahan akal ini adalah terkait dengan pola pikir umat, selanjutnya hati terkait dengan pola sikap dan hawa nafsu artinya perubahan pola perilaku. ${ }^{24}$

Kedua, Mengamalkan ajaran Islam secara konkrit. Sebagai langkah kedua dalam mendorong peran dakwah terhadap perubahan sosial adalah dengan berusaha mengamalkan ajaran Islam dalam kehidupan nyata di masyarakat secara konsisten. Sebab selama ini ada kesan bahwa semangat untuk mengetahui ajaran agama di masyarakat tidak berbanding lurus dengan semangat mengamalkan ajaran agama dalam kehidupan ril.

Oleh karena itu, peran dakwah dalam perubahan sosial maka ajaran Islam diyakini tidak hanya menyuruh umatnya untuk meraih kehidupan dunia akan tetapi harus berupaya meraih kehidupan akhirat dengan sukses. Ajaran Islam tidak pula mengenal adanya pemisahan antara hidup dunia dan akhirat, bahkan doktrin Islam menganggap kehidupan dunia adalah sarana untuk ibadah dalam upaya menggapai kebahagiaan akhirat. ${ }^{25}$

Agar dakwah berperan aktif dalam perubahan sosial di tengah masyarakat, maka materi dakwah yang diperkenalkan oleh para juru dakwah tidak boleh hanya bersifat fiqhiyah belaka yang pasti terjerumus pada masalah khilafiyah. Akan tetapi bagaimana seorang da'i mampu memberikan semangat serta motivasi dalam pentingnya umat Islam harus jadi orang kaya, sehingga dengan kekayaan tersebut ia lebih mampu memperjuangkan Islam dalam percaturan dunia ekonomi saat ini. Karea disadari hampir tidak ada sesuatu yang bisa terwujud tanpa uang (harta), walaupun harta (uang) bukan segalanya. ${ }^{26}$

Sejalan dengan hal tersebut, bahwa Islam berperan sebagai subyek sekaligus obyek, maka hakekat dakwah Islam adalah aktualisasi imani yang dimanifestasikan dalam suatu kegiatan manusia beriman, dalam bidang kemasyarakatan yang dilaksanakan secara teratur, untuk memengaruhi cara merasa, berpikir, bersikap dan bertindak manusia, pada dataran kenyataan

\footnotetext{
${ }^{24}$ Moh. Ali Aziz, Ilmu Dakwah, (Jakarta: Prenada Media Kencana, 2004), h. 454-455.

${ }^{25}$ Didin Hafidhuddin, Dakwah Aktual, (Jakarta: Gema Insani, 1998), h. 19.

${ }^{26}$ QS. al-Jumuah: 10 .
} 
individual dan sosio-kultural dalam rangka mengusahakan terwujudnya ajaran Islam dalam semua segi kehidupan umat manusia. ${ }^{27}$

Dalam hal ini, Islam pada hakekatnya hendaklah membawa perubahan; yaitu perubahan dari yang tidak beriman menjadi beriman, dari yang beriman menjadi lebih beriman (takwa), dari yang tidak baik menjadi lebih baik, dan dari yang baik menjadi lebih baik. Oleh karena itu, Islam dalam sistemnya, hendaklah memiliki fungsi mengubah lingkungan secara lebih terinci dengan meletakkan dasar eksistensi masyarakat yang berkultur dan berkarakter yang Islami, sehingga penanaman nilai-nilai keadilan, persamaan, persatuan, perdamaian, kebaikan, dan keindahan sebagai penggerak perkembangan masyarakat menjadi pilar dalam pengembangan Islam. Selain itu, membebaskan individu dan masyarakat dari sistem yang zalim (tirani, totaliter) menuju sistem yang adil, menyampaikan kritik sosial atas penyimpangan yang berlaku dalam masyarakat, dalam rangka mengemban tugas nahi munkar dan memberi alternatif konsepsi atas kemacetan sistem dalam rangka melaksanakan amar makruf dengan berdasar nilai-nilai ajaran Islam.

Meskipun diakui adanya perbedaan, tidak bisa kita pungkiri adanya titiktitik temu yang menghubungkan budaya Islam secara universal. Salah satu titik temu itu berupa komitmen masing-masing pribadinya pada kewajiban menjalankan setiap usaha untuk menciptakan masyarakat yang sebaik-baiknya di muka bumi ini. ${ }^{28}$

Totalitas risalah Nabi Muhammad saw. adalah untuk semua manusia, bahkan juga jin. Risalahnya berlaku sepanjang masa tanpa batasan ruang dan waktu. ${ }^{29}$ Manusia dengan seluruh dinamika sosial dan geografisnya berusaha Islam dihadirkan kepada mereka dalam upaya turut berbicara dan memberi solusi dari berbagai kompleksitas manusia sebagai mahluk sosial. Islam sebagaimana telah dipahami jangan hanya diarahkan pada masalah-masalah yang cenderung

\footnotetext{
${ }^{27}$ Amrullah Ahmad, Dakwah Islam dan Perubahan Sosial, (Yogyakarta: Prima Duta, 1983), h.2.

${ }^{28}$ Nurcholih Madjid, Tradisi Islam, Peran dan Fungsinya Dalam Pembangunan di Indonesia, (Cet.1; Jakarta: Paramadina, 1997), h. 90-91.

${ }^{29}$ Sa'id Bin 'Ali bin Wahif al-Qahtani, Op. cit., h. 354.
} 
tidak membuat "tertarik" untuk mendengarkannya. Dalam arti orientasi da'i harus adaptip terhadap kondisi sosial dan budaya. Dengan catatan sepanjang wilayah dan praktek kebudayaan tersebut diketahui tidak bertentangan dengan nilai-nilai ketuhanan dan filosofis Islam.

Dengan demikian dakwah jika diaplikasikan secara universal maka akan mampu memberikan perubahan yang signifikan terhadap masyarakat baik sebagai invidu maupun kolektif.

Dalam prespektif historis, pergumulan Islam sebagai agama dengan realitas sosio-kultur terdapat dua kemungkinan. Pertama, Islam mampu memberikan out-put (hasil, pengaruh) terhadap lingkungan dalam arti memberi dasar filosofi, arah, dorongan dan pedoman perubahan masyarakat sampai terbentuknya realitas sosial yang baru. Kedua, Islam dipengaruhi oleh eksistensi, corak dan arahnya. Ini berarti bahwa aktualitas Itukan oleh sistem sosio-kultural. Dalam kemungkinan yang kedua ini, sistem Islam bersifat statis atau ada dinamika namun kurang berarti bagi perubahan sosio-kultural. ${ }^{30}$ Selanjutnya dalam pandanga kuntowijoyo agar misi Islam dalam bahasa dakwah mampu memberikan perubahan sosial secara sihnifikan maka misi agama Islam harus dipahami adalah mencoba mentransformasikan dinamika-dinamika yang dimiliki, dan hal ini terus-menerus mendesak akan adanya transformasi sosial. Islam memiliki cita-cita ideologis yaitu menegakkan amar ma'ruf dan nahi munkar dalam masyarakat di dalam kerangka keimanan kepada Tuhan. Sementara amar ma'ruf berarti humanisasi dan emansipasi, nahi munkar merupakan upaya untuk liberasi. Dan karena kedua tugas ini berada dalam kerangka keimanan, maka humanisasi dan liberasi merupakan dua sisi yang tidak dapat dipisahkan dari transendensi. Di setiap masyarakat, dengan struktur dan sistem apapun, dan dalam tahap historis yang manapun, cita-cita untuk humanisasi, emansipasi, liberasi dan transendensi akan selalu memotifasikan Islam. ${ }^{31}$

Karena itu ajaran Islam adalah konsepsi yang sempurna dan komprehensif,

\footnotetext{
${ }^{30}$ Amrullah Ahmad, Op.cit., h. 2.

${ }^{31}$ Kuntowijoyo, Paradigma Islam: Interpretasi Untuk Aksi, (Bandung: Mizan, 1995), h. 3.
} 
karena ia meliputi segala aspek kehidupan manusia, betapapun hanya garis besarnya saja, baik yang bersifat duniawi maupun ukhrawi. Islam secara teologis, merupakan sistem nilai dan ajaran yang bersifat Ilahiyah dan transenden. Sedangkan dari aspek sosiologis, Islam merupakan fenomena peradaban, kultural dan realitas sosial dalam kehidupan manusia. Paham ini memberi pengertian bahwa Islam adalah jalan hidup yang total dan utuh, baik masalah duniawi maupun ukhrawi; yang merupakan seperangkat keyakinan dan tata peribadatan sistem hukum yang total dan utuh serta merupakan suatu peradaban dan kebudayaan. Karena itu, Islam menyediakan seperangkat nilai-nilai normatif bagi kehidupan sosial.

Transformasi yang terjadi di dalam konsep dan praktik dakwah menunjukkan betapa pengkajian ulang terhadap konsep-konsep dasar Islam melibatkan tidak hanya elite negara dan intelektual, tetapi juga massa. Perubahan tidak hanya diawali dari puncak masyarakat, sebagaimana yang biasa terjadi, tetapi juga dari bawah. Pendidikan merupakan hal yang sentral dalam seluruh konseptualisasi dakwah. Melalui kerja para da'i, Muslim maupun non Muslim memperoleh suatu pemahaman tentang hidup berdasarkan Islam. ${ }^{32}$

\section{KESIMPULAN}

Pada prinsipnya Islam dan budaya tidak bertentangan, sebab keduanya sama-sama mengajarkan nilai-nilai kebaikan yang tujuannya membuat keteraturan bagi sekelompok manusia.

Karena itu, dalam konteks dakwah maka yang terpenting adalah bagaimana seorang da'i harus mampu memahami nilai-nilai historis dan filosofis dari budaya yang berkembang di masyarakat, kemudian diinternalisasi dengan nilai-nilai keislaman. Walhasil lahirlah model budaya baru yang bisa disebut "budaya Islami".

Islam mengajarkan kepada manusia nilai-nilai normatif untuk menerapkan keadilan, kejujuran, persamaan, kebebasan, persaudaraan, kebebasan dan

\footnotetext{
${ }^{32}$ Dale F. Eickelman dan James Piscatori, Ekspresi Politik Muslim, terj. Rofik Suhud,
} (Cet. I; Bandung: Mizan, 1998), h. 48. 
musyawarah, yang kesemuanya itu dalam rangka mewujudkan suatu tata kehidupan masyarakat dan negara yang sebaik-baiknya untuk kemaslahatan hidup yang berkesinambungan, baik kehidupan individual maupun kehidupan sosial. Dan bahwa "pada dasarnya universalisme ajaran (agama) Islam telah memuat prinsip-prinsip dasar mengenai hubungan-hubungan individu dan hubunganhubungan sosial yang kemudian pengejawantahan nilai-nilai kemanusiaan tersebut secara subtansial.

\section{DAFTAR PUSTAKA}

Ahmad, Amrullah. Dakwah Islam dan Perubahan Sosial, Yogyakarta: Prima Duta, 1983.

Ali Aziz, Moh. Ilmu Dakwah, Jakarta: Prenada Media Kencana, 2004.

Alisyahbana, Sutan Takdir. Antropologi Baru, Jakarta: Dian Rakyat, 1986.

al-Qahtani, Sa'id Bin 'Ali bin Wahif. Al-H\{ikmah fi al-Da'wah ila Allah Ta'ala, terj. Mansyur Hakim, Dakwah Islam Dakwah Bijak, Cet. I; Jakarta: Gema Insani Press, 1994.

Aripudin, Acep. Sosiologi Dakwah, Bandung: Rosda Karya, 2013.

Bungin, Burhan. Sosiologi Komunikasi: Teori, Paradigma dan Diskursus Teknologi Komunikasi di Masyarakat, Cet. IV; Jakarta:Kencana Prenada Group, 2009.

F. Eickelman, Dale., dan James Piscatori, Ekspresi Politik Muslim, terj. Rofik Suhud, Cet. I; Bandung: Mizan, 1998.

Hafidhuddin, Didin. Dakwah Aktual, Jakarta: Gema Insani, 1998.

Imam Al-Qurthubi, Tafsir Al-Qurthubi Juz 5, alih bahasa Ahmad Rijali Kadir, Jakarta: Pustaka Azzam, 2008.

Jurdi, Syarifuddin. Sosiologi Islam dan Masyarakat Modern, Yogyakarta: Kencana Prenada Media Group, 2010.

Kuntowijoyo, Paradigma Islam: Interpretasi Untuk Aksi, Bandung: Mizan, 1995.

Madjid,Nurcholih. Tradisi Islam, Peran dan Fungsinya Dalam Pembangunan di Indonesia, Cet.1; Jakarta: Paramadina, 1997.

Muhiddin, Asep. Dakwah Dalam Perspektif Al-Qur'an, Bandung: Pustaka Setia, 2002.

Munir Amin, Syamsul. Rekonstruksi Pemikiran Dakwah Islam, Cet. I; Jakarta: AMZAH, 2008.

Nata, Abuddin. Metodologi Studi Islam, Cet. XIX; Jakarta: Raja Grafindo Persada, 2012.

, Peta Keragaman Pemikiran Islam Di Indonesia, Jakarta: Raja Grafindo Persada, 2001. 
Poerwadarminta, W.J.S. Kamus Umum Bahasa Indonesia, Jakarta: Balai Pustaka, 1991.

Shihab, M. Quraish. Tafsir Al-Misbah Volume VIII, Cet.IV; Jakarta: Lentera Hati, 2005.

Suaedy, Ahmad. Perspektif Pesantren; Islam Indonesia Gerakan Sosial Baru Demokratisasi, Cet. I; Jakarta: The Wahid Institut, 2009.

Taylor, E.B. dalam, Deddy Mulyana dan Jalaluddin Rakhmat (ed.), Komunikasi Antar Budaya: Panduan Berkomunikasi Dengan Orang-Orang Berbeda Budaya, Cet. XII., Bandung: Rosda Karya, 2010. 